\title{
Introduction of New Forms of Education in Modern Higher and Vocational Education and Training
}

\author{
Liudmyla I. Berezovska ${ }^{1}$, Galyna D. Kondratska², Anna A. Zarytska ${ }^{3}$, Kateryna S. Volkova ${ }^{4} \&$ Taras M. Matsevko ${ }^{5}$
}

${ }^{1}$ Faculty of Social Pedagogy and Social Work, Vasyl Stefanyk Precarpathian National University, Ivano-Frankivsk, Ukraine

${ }^{2}$ Department of Sport Disciplines and Tourism, Institute of Physical Training, Drohobych Ivan Franko State Pedagogical University, Drohobych, Ukraine

${ }^{3}$ Department of History, Theory, and Performance Arts, Faculty of Arts, Lesya Ukrainka Eastern European National University, Lutsk, Ukraine

${ }^{4}$ Department of Social Work, Faculty of Socio-Pedagogical Sciences and Foreign Philology, Kharkiv Humanitarian-Pedagogical Academy, Kharkiv, Ukraine

${ }^{5}$ Department of Moral and Psychological Support of Troops, Institute of Moral and Psychological Support, Hetman Petro Sahaidachnyi National Army Academy, Lviv, Ukraine

Correspondence: Liudmyla I. Berezovska, Vasyl Stefanyk Precarpathian National University, 57 Shevchenko str., Ivano-Frankivsk, 76000, Ukraine.

Received: June 10, 2020

Accepted: August 3, 2020

Online Published: August 4, 2020

doi:10.5430/ijhe.v9n7p107

URL: https://doi.org/10.5430/ijhe.v9n7p107

\begin{abstract}
This article sets sights on highlighting the effectiveness and efficiency of higher and vocational education and training, as well as exploring ways to address and implement the current reform agenda in the field. The research was conducted on the basis of a generalizing and comparative method, to identify the problems and development of vocational and higher education. Within the framework of the conducted research the current state of vocational and higher education has been characterized; the features of online learning at leading universities and its advantages has been clarified; the prospects of introduction of continuity of education have been studied, for the development of personality abilities, taking into account changes in society in the context of improvement of the system of vocational and higher education caused by the European integration process of education; directions for the development of vocational and higher education as part of the national education system and society in general have been outlined. It is determined, that at the present stage the domestic education system should be improved and transferred to an innovative way of development in accordance with developed countries. In the near future, such modern forms of education as: distance education, dual education, continuing vocational education and others, should be improved and implemented into the educational process.
\end{abstract}

Keywords: education, vocational education and training, higher education, development of education

\section{Introduction}

Education is the main area of social-economic life of the country, a cultural phenomenon that serves to accumulate knowledge and skills and to ensure the intellectual development of a person. The state defines education as one of the main spheres of social-economic and cultural development of society. The spread of new forms of learning and education in the modern world is an important issue. A student, studying on extramural or distance form of education, may earn a good income or expect it by the time he / she completes his / her studies. Colleges attract young full-time students who do not want to live in university cities and adult part-time students who seek courses near the place where they work or live. Their contribution to increasing participation is to attract applicants who do not want to study at universities, but this number remains low due to the low status of higher education in colleges.

The OECD "Skills Beyond School" report and post-secondary vocational training are defined as "programs and qualifications" that prepare students for certain professions or occupations that go beyond the upper secondary education levels and typically require at least six months of full or equivalent training. This report identifies three types of qualifications that meet these definitions: 
- Post-secondary qualifications requiring more than six months and less than three years of full-time (or part-time) study, generally at ISCED level 5 (International Standard Classification of Education (ISCED))

- $\quad$ Professional qualification of bachelor's degree, intended for preparation of graduates for professions;

- Professional exams (sometimes referred to as industry certifications), often do not contain requirements for fixed training programs, such as exams for accountants, for master builders and certification of proprietary software.

The above definition demonstrates the diversity that makes up higher education. It also emphasizes the close relationship of HVE with specific qualifications or competencies, often at a level below the Bachelor's degree, but also with the level of provision of the Bachelor's degree (ISCED level 6). With regard to destinations in the job market, HVE is generally positioned as a preparation for higher-level technical professions, "associated professional" roles, as defined in the UK Standard Professional Classification, differentiating it from training in professions and in management positions related to university education.

Attention should be drawn to the concept of "hybrid qualifications" - they include integration between academic and vocational education, which has become more common in Germany. Their attention is focused on another form of educational hybridity: the ever-increasing use of apprenticeships as an additive dual-qualification path by which students who complete the Abitur academic qualifications do not enter directly the university, but are initially taught and trained.

Worthy of separate attention is the program implemented in five states of the USA, based on a loan accumulation system designed to withdraw participants from short mandates to completing long-term qualifications in order to achieve upward mobility among the poor. The document demonstrates the importance of a detailed breakdown by factors such as gender, ethnicity, and social-economic background in attempting to assess the impact of such initiatives. The analysis testified that, although the strategy encouraged the transition from shorter programs to longer mandates, there were significant differences across ethnic lines, especially regarding completion and progress.

The aim of the article is to study and analyze innovative trends in the field of vocational and higher education in the world, to determine the most effective and modern forms of education that can be implemented in the educational process in Ukraine.

\section{Methods}

Methods of analysis and synthesis were used in the process of research in order to determine the leading tendencies and their influence on the Ukrainian educational system, peculiarities of national tendencies. We examined how the goals of sustainable development of countries and their education system intersect, as well as expectations regarding future education (Lindgren \& Oehman, 2018). We studied the behaviors of modern teachers in vocational and higher education (Corney \& Reid, 2007). The scientific abstraction method and the systematic method were used to identify and systematize the problems of functioning and development of the educational sphere in Ukraine, their causes and consequences. We examined the features of the Ukrainian educational system development (secondary, vocational and higher) during the economic and political crisis (Lunyachek, 2011). The systematic approach and the statistical method were used to study the state of development of vocational and higher education in Ukraine. We studied the methods of public administration of the education system and the categories of the process of implementing educational changes (Semenets-Orlova, 2018). The analysis and synthesis of information were used to study international educational development experience. Prognostic methods were used to set goals for the development of vocational and higher education and training in Ukraine. The analysis of the following indicators was carried out in the study:

1. Participation of adults in gender-specific education, aged 25-64, in \% (Eurostat, 2014).

2. World University in 2020 (The Times Higher Education, 2020).

3. The features of online learning at leading universities (Duffin, 2020).

4. Advantages for online learning for students in 2018 (Duffin, 2020).

5. Amount of financial aid to students by level of education as a percentage of total public expenditure (Eurostat, 2020).

6. Public and private expenditure on education, \% of GDP (World Bank, 2018).

The practice of introducing new forms of education is considered at Freie Universitat (Germany), Stockholm University (Sweden), Trinity College Dublin (Ireland), Oxford University (UK). 


\section{Literature Review}

Problems and trends in the functioning and development of education have been considered by leading researchers, in particular:

Gallivor and Bradley (2012) describe the transformation a school has undergone as part of the project "Adventure School", creating a new vision, relationships with the community, and different curricular programs: "respect the inconspicuous, quiet experiments in which professional teachers take part daily to re-inspire sources of civic education".

From the point of view of S. Whitehouse it follows that: "learning from generation to generation is one of the ways, perhaps the best one, contributing to collective wisdom and innovation. Such education is necessary for cultural and evolutionary change. Now we need to reinvent the ways that generations can use for learning, working and playing together" (Maslova, 2004).

According to Gerald W. Bracey, who, revealing the "secret of American education", noted: "we need to think a hundred times before making a hash of our education and neglecting the experience of the American education system that encourages to asking questions. We will not benefit from those who worship high test results" (Maslova, 2004).

A significant role in the development of the American education system was played by the scientist, Director of the Center for Effective Schools at Washington University, Jerry Bamburg, who noted: "changes are rarely institutionalized through content enrichment and training programs, the development of a school organization and assessment methods in line with the stated purpose".

According to Tkachenko (2015), "the problem is aggravated by the fact that the attention is not paid to training of employees; numerous researches testify to extremely low indicators of vocational training / retraining of the personnel of the enterprises, the infrastructure of adult education is underdeveloped; the educational institutions are oriented almost exclusively on primary vocational training for young people".

As noted by Ogneviuk (2014): “According to the World Bank 2012 estimates, Ukraine ranked the 56th place among 146 countries in the rating of the Knowledge Economy Index; it's one of the main criteria is the level of education and training of the population".

\section{Results and Discussion}

The system of generation and transfer of knowledge has changed dramatically over the past decades, and their volume has grown many times. Currently, about $5 \%$ of theoretical and $20 \%$ of professional knowledge is updated annually. The solution to the problem lies in the transition to lifelong learning, where basic education should periodically be supplemented by extended education programs and organized not as a final, completed, but only as a basis, a foundation, supported by other programs. The Figure 1 shows the education level of people aged 15-64.

Adult participation in learning by sex \% of population aged 25 to 64

\section{Total}

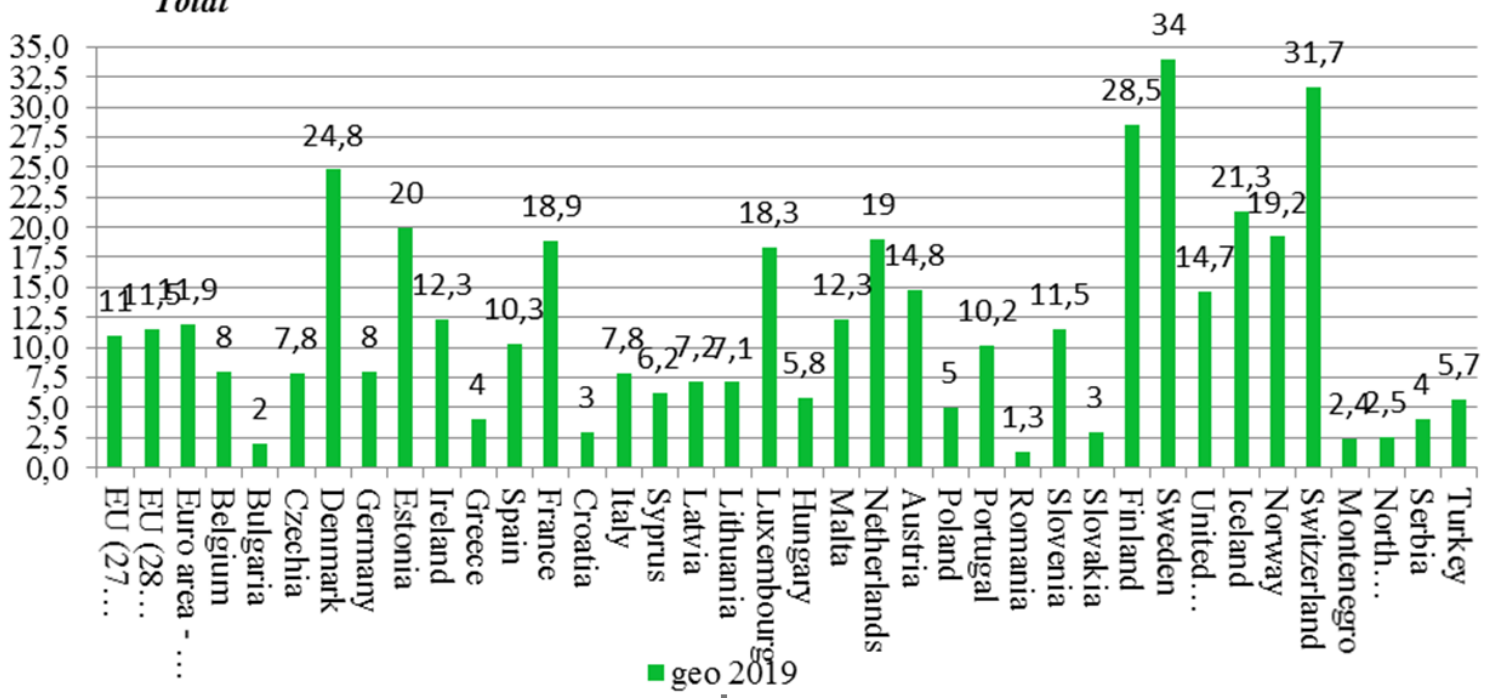

Figure 1. Participation of adults in gender-specific education, aged 25-64, in \% (Eurostat, 2014) 
It can be seen from Figure 1 that the highest level of education among the population aged 25-64 is in Finland, Sweden and Switzerland.

The World University Rankings 2020 include almost 1,400 universities across 92 countries, in Table 1 we choose 10 the most famous and high-level, which provide best teaching, research and international cooperation.

Table 1 World University in 2020 (The Times Higher Education, 2020)

\begin{tabular}{|c|c|c|c|c|c|}
\hline Rank & Name Country/Region & $\begin{array}{l}\text { No. of FTE } \\
\text { Students }\end{array}$ & $\begin{array}{l}\text { No. of students } \\
\text { per staff }\end{array}$ & $\begin{array}{l}\text { International } \\
\text { Students }\end{array}$ & $\begin{array}{l}\text { Female: Male } \\
\text { Ratio }\end{array}$ \\
\hline 1 & $\begin{array}{l}\text { University of Oxford, United } \\
\text { Kingdom }\end{array}$ & 20,664 & 11.2 & $41 \%$ & $46: 54$ \\
\hline 2 & $\begin{array}{c}\text { California Institute of } \\
\text { Technology, United States }\end{array}$ & 2,240 & 6.4 & $30 \%$ & $34: 66$ \\
\hline 3 & $\begin{array}{l}\text { University of Cambridge, } \\
\text { United Kingdom }\end{array}$ & 18,978 & 10.9 & $37 \%$ & $47: 53$ \\
\hline 4 & $\begin{array}{c}\text { Stanford University, United } \\
\text { States }\end{array}$ & 16,135 & 7.3 & $23 \%$ & $43: 57$ \\
\hline 5 & $\begin{array}{l}\text { Massachusetts Institute of } \\
\text { Technology, United States }\end{array}$ & 11,247 & 8.6 & $34 \%$ & $39: 61$ \\
\hline 6 & $\begin{array}{c}\text { Princeton University, United } \\
\text { States }\end{array}$ & 7,983 & 8.1 & $25 \%$ & $45: 55$ \\
\hline 7 & $\begin{array}{l}\text { Harvard University, United } \\
\text { States }\end{array}$ & 20,823 & 9.2 & $24 \%$ & $49: 51$ \\
\hline 8 & $\begin{array}{l}\text { Yale University, United } \\
\text { States }\end{array}$ & 12,402 & 5.4 & $20 \%$ & $50: 50$ \\
\hline 9 & $\begin{array}{l}\text { University of Chicago, } \\
\text { United States }\end{array}$ & 13,833 & 5.7 & $28 \%$ & $46: 54$ \\
\hline 10 & $\begin{array}{l}\text { Imperial College London, } \\
\text { United Kingdom }\end{array}$ & 16,760 & 11.7 & $56 \%$ & $38: 62$ \\
\hline
\end{tabular}

Distance education or distance learning is the education of people who may not always be physically present in the educational establishment. A distance learning program can be full distance learning or a combination of distance learning and traditional classroom instruction (called hybrid or blended).

From these universities the best providers of online education in our opinion are:

1. Freie Universitat (Germany) - education are mainly free for all students, in spite of the nationality, but some online courses can cost about 9500 EUR in a year, it is appropriate for all academic levels.

2. Stockholm University (Sweden) - has a huge amount of students, which pay time to research, especially in science and the humanities. Online courses cost about 13,000 EUR per academic year and are offered for master's level.

3. Trinity College Dublin (Ireland) - is the best in Ireland and provide online courses with the price from 3,500 to 11,200 EUR per academic year.

4. Oxford University (UK) - is one of the most famous and best in the world with high educational standards, the best professors and quality of education. Online courses are mainly for master's level with price from 1,800 to 16,500 EUR per academic year.

Massive Open Online Courses (MOOC), offering large-scale interactive participation and open access through the World Wide Web or other networking technologies, are the latest educational modes of distance education. A number of other terms (distributed learning, e-learning, m-learning, online learning, virtual class, etc.) are used approximately synonymously with distance education. In the Figure 2 it is shown the ways of online learning in the most of European Universities.

All materials, tasks and training programs are sent online or by mail. Advantages of distance learning include:

- $\quad$ Distance learning offers much more freedom; 
- $\quad$ Opportunity to study in your spare time without incurring additional expenses such as business expenses;

- $\quad$ Opportunity to work and earn while studying outside working hours;

- $\quad$ Opportunity to gain experience while working. Companies often pay for training through distance learning;

- $\quad$ Achieving all goals at the same time;

- Improving your own results through distance learning as an alternative or as a way to better education.

Reasons for online learning for students in 2018 is shown in Figure 3.

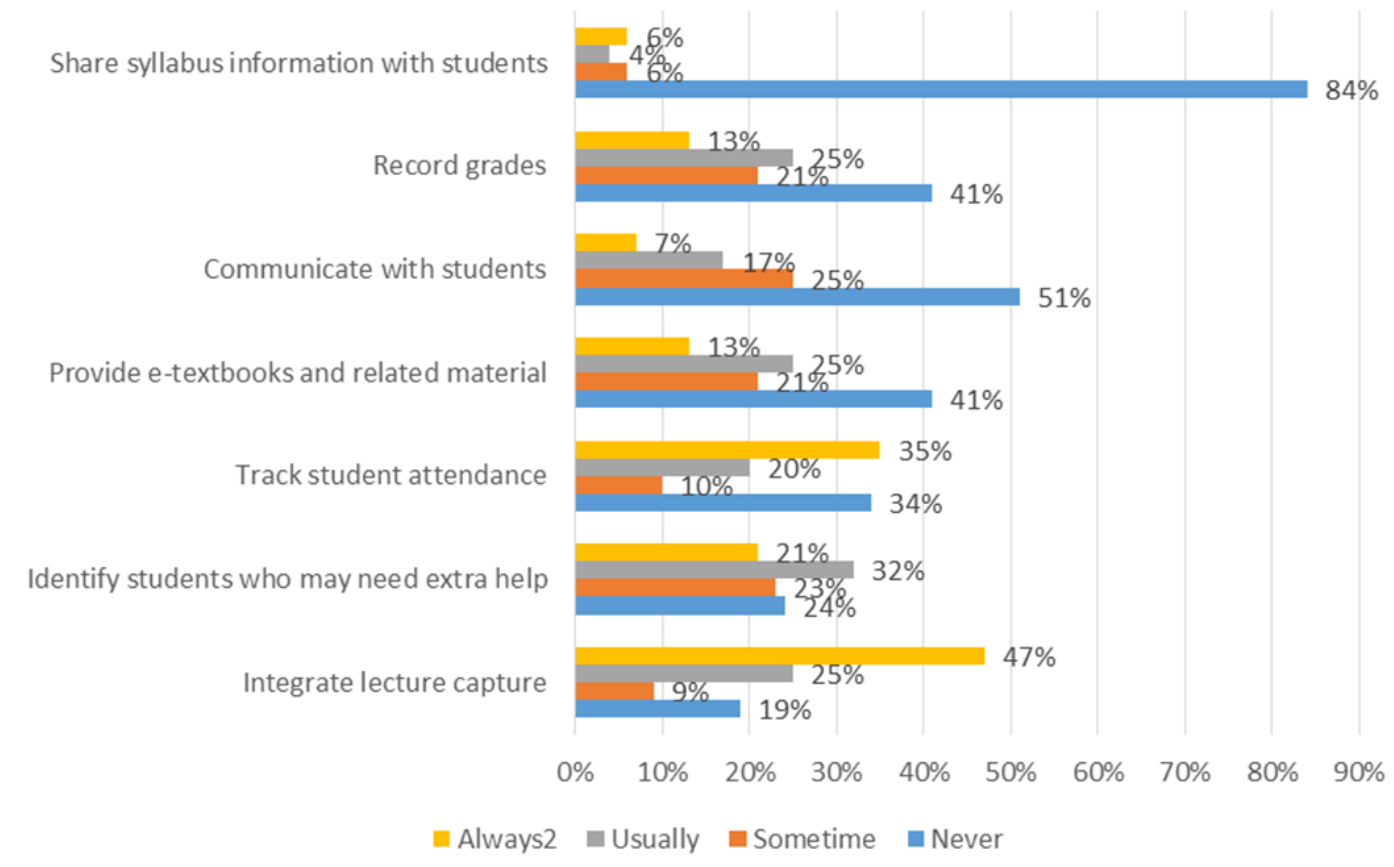

Figure 2. The features of online learning at leading universities (Duffin, 2020)

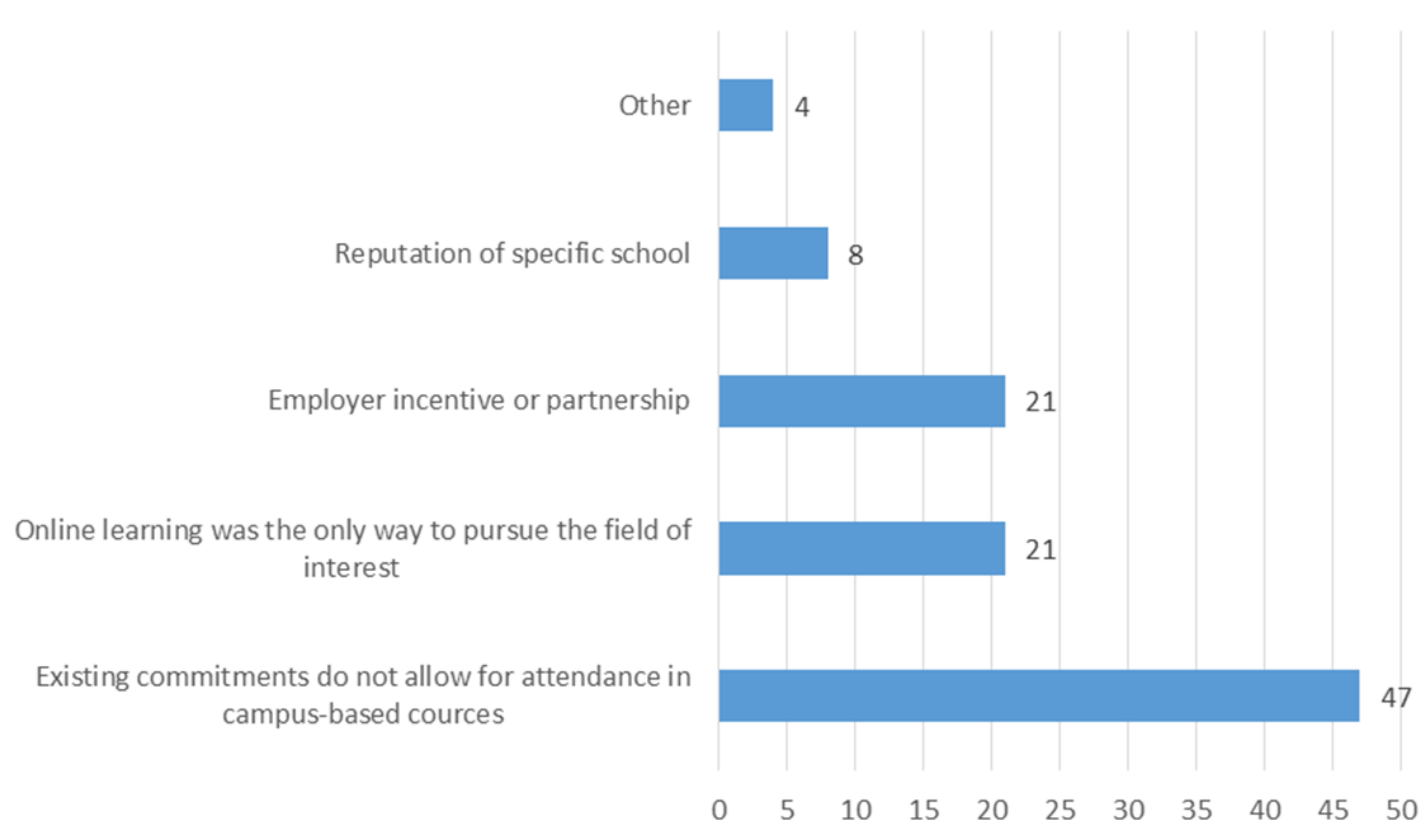

Figure 3. Advantages for online learning for students in 2018 (Duffin, 2020) 
Gradual change in the architectonics of higher education takes place with the development of modern technologies. Nations - states seek to control and influence universities and the higher education system, which are seen as tools for the transfer of social norms and values and are a buffer between generations. The Open University is one of such new forms; its task is to provide accessible distance learning. There is already a variety of the universities in several countries: the Open University in Great Britain, the Open University of the Netherlands, the Open University of Israel, Sukhothai Open University of Thammathirat in Thailand. However, distance learning can take other forms. Many universities in the US and Europe have so-called MOOC (Massive Open Online Courses); The Massachusetts Institute of Technology, Stanford and Harvard Universities are developing free LMS (Learning Management System) platforms for e-learning.

The University Network is the next new form, which originates from the eastern part of the world and is an association of individual universities from different countries. They provide a comprehensive academic program based on the concept of a cultural and educational paradigm. In particular, SCO (Shanghai Cooperation Organization) and the BRICS Network University (Brazil, Russia, India, China and the South Africa) are Network Universities that have been created by analogy with the Bologna Process.

Educational resources or online resources that are online and in open access, such as: Coursera, Academic Earth, edX, iversity, and others, are viewed by some professionals as competitive or alternative forms of higher education. Coursera deserves special attention like the largest platform for free academic online education with hundreds of different courses from 62 universities in America, Europe, Asia and Australia. Offered courses are in English, French, Spanish, Italian and Chinese for different disciplines.

The educational and training initiatives united by the European Commission into a single Lifelong Learning Program need further attention. This program has replaced the vocational and distance learning programs that existed prior 2006. The Council of Europe has approved lifelong learning as one of the main components of the European social model. Such training is not limited only to the field of education; it is also a critical factor in the areas of employment and social security, economic growth and competitiveness.

Educational functions are implemented not only by educational institutions regulated by the state. Large enterprises may have divisions or departments engaged in advanced training and retraining or at their own educational base or order the training of their employees in external educational establishments. In particular, this principle is used by Ukrtelecom, METRO (Zdioruk, 2011).

As of today, there are three basic forms of education:

- Formal education - elementary, general secondary education, secondary vocational education, higher education, post-graduate education (postgraduate and doctoral studies), advanced training and retraining of specialists and managers with higher and secondary vocational education in institutes, faculties and advanced courses of professional retraining;

Non-formal education - vocationally oriented and general cultural courses, training at centers, adult education, on television, at various intensive training courses. Non-formal education is as any educational activity during working or non-working hours among professionals, friends, family, which is not structured, organized or planned. Besides, it is the educational process, which corresponds to the structure of this activity, acquires an organized form, does not belong to the state programs of compulsory education and is determined by purposefulness (Colley, Hodkins \& Malcom, 2003).

- Informal education is a general term for education outside the standard educational environment - individual cognitive activity that accompanies daily life; it is carried out at the expense of individuals' own activity in the surrounding cultural and educational environment; communication, reading, visiting cultural institutions, traveling, mass media, etc. Herewith, the person transforms the educational potential of society into effective factors of its development (Zdioruk, 2011).

Dual education is another new form of learning. Dual education system combines company apprenticeship and vocational education at vocational school in one course. This system is implemented in several countries, in particular in Germany, Austria, Switzerland and the German-speaking community of Belgium, as well as in South Korea for several years.

The term "dual system" (from the Latin "dualis" - means double) was introduced into pedagogical terminology in the middle of the 1960s in Germany as a new, more flexible form of vocational training organization. Duality as a methodological characteristic of vocational education implies a coordinated interaction of the educational and industrial sphere with the training of qualified personnel of a certain profile in the framework of organizational and 
variable forms of training (Ishchenko, 2014). The basic task of introducing dual-form training elements is to eliminate the main shortcomings of future skilled workers' traditional forms and methods of training, to bridge the gap between theory and practice, education and production, and to improve the quality of training of qualified personnel, taking into account the requirements of employers in the framework of new organizational and variable forms of training.

Features of dual education and the scheme of interaction of its participants are presented in Figure 4. Dual education is formed when there is a market need for highly qualified workers with the condition of forecasting for several years on the demand for certain specialties.

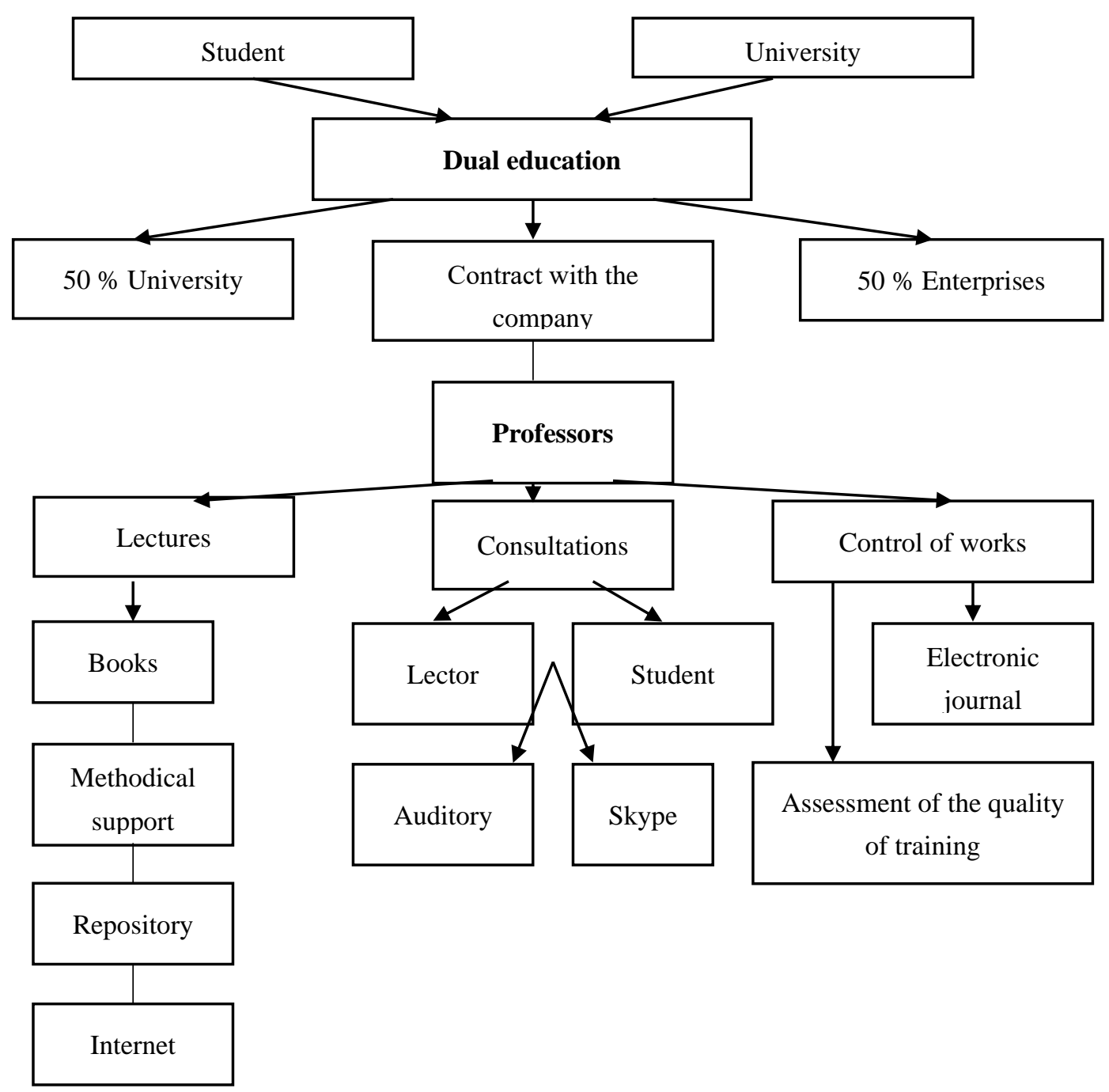

Figure 4. Scheme of dual education

Positive indicators of dual education include:

- Organization of cooperation of politicians, business and social partners;

- Developing a legal basis for recognition of national quality standards for vocational education;

- $\quad$ Training students during work activities;

- Involvement of qualified production staff in pedagogical activities (instructors, teachers);

- Conducting institutional researches and counseling (monitoring the quality of the provision of educational services in the field of vocational education, updating educational standards);

- Taking into consideration specific requests of enterprises for the content and quality of vocational education. 
In Ukraine the dual system of education can be formed on the next legislation:

the Law of Ukraine "On Education", Medium-term plan of priority actions of the government for the period 2017-2020, Order of the Ministry of Education and Science of Ukraine № 298 "On the introduction of elements of the dual system of education in the training of skilled workers", The Concept of Dual Education, approved by the Cabinet of Ministers of Ukraine.

The prospects of implementation a dual form of education in 2017-2020, according to the Ministry of Education and Science of Ukraine are:

- $\quad$ To make changes to the content of education and the schedule of the training and production process in accordance with the requests of employers and requirements of standards;

- To develop draft educational standards, which were made and based on the competency approach and block-modular construction of the educational process;

- To cooperate closely with employers to expand the number of vocational education institutions and increase the list of working professions, for which dual form of education is appropriate (Ministry of Education and Science of Ukraine, 2018).

Financing of the education system is insufficient in Ukraine. Ukraine faces severe macroeconomic vulnerability and carries a heavy fiscal burden, including the need to repay significant state debt20. This means that there is no opportunity to increase the costs of implementing the education reform program and making investments in this sphere; therefore, it is necessary to ensure the most efficient use of existing resources.

The Table 2 below shows the amount of financial aid to students by level of education - as a percentage of general government employees. As a result, Bulgaria, Norway and the Netherlands have the highest level of funding.

Table 2. Amount of financial aid to students by level of education as a percentage of total public expenditure (Eurostat, 2020)

\begin{tabular}{cccccc}
\hline Year & 2012 & 2013 & 2014 & 2015 & 2016 \\
Country & & & & & \\
\hline EU 27 countries (from 2020) & $:$ & $:$ & $:$ & $:$ & $:$ \\
Belgium & 5.5 & 5.4 & 5.4 & 5.5 & 5.4 \\
Bulgaria & 17.5 & 22.2 & 21.2 & 21.3 & 21.6 \\
Czech Republic & 3.5 & 3.7 & 3.6 & 3.4 & 3.6 \\
Denmark & $:(\mathrm{d})$ & $:(\mathrm{d})$ & $:$ & $:$ & $:$ \\
Germany (until 1990 former territory of the FRG) & 10.3 & 10.0 & 9.6 & 9.4 & 9.0 \\
Estonia & $4.0(\mathrm{~d})$ & $3.1(\mathrm{~d})$ & $:(\mathrm{d})$ & $:(\mathrm{d})$ & $:(\mathrm{d})$ \\
Ireland & 8.8 & 9.1 & 9.4 & 15.4 & $:(\mathrm{d})$ \\
Greece & $0.2(\mathrm{~d})$ & $0.2(\mathrm{~d})$ & $0.2(\mathrm{~d})$ & $0.1(\mathrm{~d})$ & $:$ \\
Spain & 3.7 & 3.5 & 4.3 & 4.1 & 4.1 \\
France & 4.2 & $4.3(\mathrm{~d})$ & 4.3 & 4.4 & 4.4 \\
Croatia & $:$ & $:(\mathrm{d})$ & $:(\mathrm{d})$ & $:$ & $:$ \\
Italy & 6.2 & 6.1 & 6.7 & 6.5 & 6.7 \\
Cyprus & 6.4 & 5.3 & 4.8 & 5.3 & 4.2 \\
Latvia & 5.6 & 4.4 & 3.3 & 3.3 & 3.9 \\
Lithuania & $3.4(\mathrm{~d})$ & $:(\mathrm{d})$ & 3.2 & 3.3 & 3.2 \\
Luxembourg & 2.5 & $:$ & 1.9 & 1.6 & 2.1 \\
Hungary & 5.6 & 5.7 & $(\mathrm{~d})$ & $5.1(\mathrm{c})$ & 3.5 \\
Malta & 8.0 & 7.2 & 8.3 & 7.0 & 6.9 \\
Netherlands & 11.0 & 11.5 & 13.3 & 11.8 & 15.1 \\
\hline
\end{tabular}




\begin{tabular}{cccccc}
\hline Austria & 4.5 & 4.0 & 4.3 & 4.0 & 3.9 \\
Poland & 3.5 & 4.4 & $4.3(\mathrm{~d})$ & 3.8 & 3.7 \\
Portugal & $:(\mathrm{d})$ & 5.2 & $5.0(\mathrm{~d})$ & $5.2(\mathrm{~d})$ & 5.1 \\
Romania & 4.8 & 5.5 & 2.2 & 2.0 & 2.5 \\
Slovenia & 5.1 & 4.1 & 4.6 & 5.1 & 5.0 \\
Slovakia & $:$ & 5.2 & 4.7 & 3.9 & 4.2 \\
Finland & $5.9(\mathrm{~d})$ & 5.9 & 6.0 & 6.0 & 6.0 \\
Sweden & $:$ & 10.1 & 10.1 & 10.2 & 9.6 \\
United Kingdom & 6.5 & 7.0 & 14.4 & $16.4(\mathrm{~d})$ & 16.5 \\
Iceland & 6.5 & $6.6(\mathrm{~d})$ & 6.0 & 5.5 & 6.4 \\
Liechtenstein & $:$ & $:(\mathrm{d})$ & $:(\mathrm{d})$ & $:(\mathrm{d})$ & $:(\mathrm{d})$ \\
Norway & $:(\mathrm{d})$ & $12.8(\mathrm{~d})$ & 15.4 & 10.7 & 10.7 \\
Switzerland & $:$ & 1.4 & 1.4 & 1.3 & 1.3 \\
Serbia & $:$ & $:$ & $:$ & 0.0 & $:$ \\
Turkey & $:(\mathrm{d})$ & $:$ & $:$ & $:(\mathrm{d})$ & 7.6
\end{tabular}

Flags available: $\mathrm{b}$ - break in time series, $\mathrm{u}$ - low reliability, $\mathrm{c}$ - confidential, $\mathrm{f}$ - forecast, $\mathrm{e}$ - calculation, $\mathrm{p}$ - temporary, $\mathrm{r}$ - has been reviewed, $\mathrm{z}$ - not applicable, $\mathrm{d}$ - the definition is different, see metadata, $\mathrm{n}$ - not significantly, $\mathrm{s}$ - Eurostat estimate.

Total expenses for education include expenditures for education from preschool to higher, including expenses not related to a specific level. After a sharp depreciation of the national currency in 2013, state expenditures on education in real terms fell by $35 \%$ in two years. Budget financing of education decreased from $7.2 \%$ of GDP in 2013 to $6.0 \%$ in 2017 (See Figure 5).

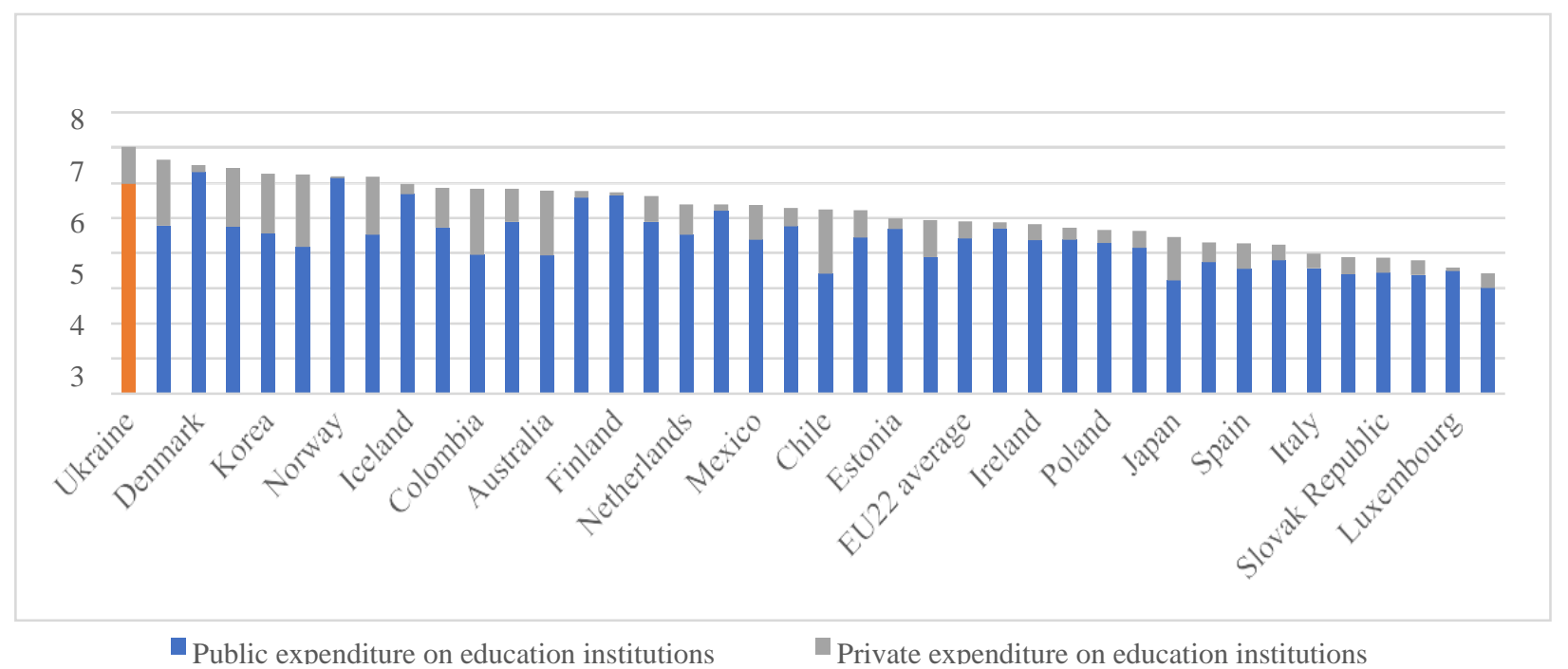

Figure 5. Public and private expenditure on education,\% of GDP (World Bank, 2018).

This falling has brought Ukraine closer to comparative international indicators on the share of national wealth spent on education, however the expenditure level remains high: considering that state expenditures on education amount $6.0 \%$ of GDP, while private expenditures amount another percentage point, education' expenditure level in Ukraine is among the highest in the world. One of the reasons for this is a provision in the law that requires the state to target at least 7 percent of GDP. However, Ukraine is faced with a serious macroeconomic vulnerability and carries a heavy fiscal burden, including the need to repay large amounts of state debt. This means that there is no opportunity to increase the costs of implementing the education reform program and investing in this field, and therefore it is necessary to make the best use of existing resources. 
According to the functional classification, the overwhelming share of budgetary funds is directed to financing of general secondary education ( $41.5 \%$ of budget allocations for education), higher education $(30.9 \%)$, pre-school education $(11.7 \%)$ and vocational technical education $(6,2 \%)$. The remaining funds $(9.7 \%)$ are spent on financing postgraduate education, extracurricular education and out-of-school activities with children, educational support programs, research and development in the field of education, and other institutions and activities in the field of education.

The National Academy of Pedagogical Sciences of Ukraine developed the Concept of development of vocational (technical) education of Ukraine in 2004. This document substantiates the purpose, principles and priorities for the development of vocational education and training. Vocational education institutions were intended to cover the following categories of population: young people enrolled in vocational schools; students of higher educational establishments who acquire working professions at vocational schools; production staff of various economic sectors; unemployed citizens who are directed to vocational training on the request of the state employment service; other citizens who need to obtain initial vocational training or wish to change their profession (Ishchenko, 2014).

Educational and practical centers of sectoral orientation are created on the basis of institutions of vocational (vocational-technical) education at the expense of the state budget, the results of which are the growth of the general contingent of students, students of vocational educational institutions; increasing the number of graduates who are employed by the profession; as well as internships at such centers of industrial training masters and teachers of special subjects.

Elements of dual form of training ensure the completion of industrial training and production practice in the production environment within $60-70 \%$ of study time, which provides the opportunity to carry out practical training on modern equipment using innovative technologies and to ensure the proper quality of professional training of skilled workers, taking into account the needs and requests of employers.

The concepts developed by the Institute of Vocational Education of the National Academy of Pedagogical Sciences of Ukraine are aimed at ensuring permanency and continuity in providing quality training of production personnel in educational establishments of different types and forms of ownership and in production sphere. The concept of development of adult education in Ukraine was implemented by the Institute of teachers' education and adult education of the Academy of Pedagogical Sciences of Ukraine. The following key means of ensuring the advanced development of the national educational and scientific system, requiring maximum attention at the state level, should be noted:

1. Developing a modern National Qualifications System as a prerequisite for the creation of a single educational space integrated into the European one;

2. Lifelong learning is a major trend in modern education;

3. Introduction of elements of open education as a means of improving the quality of education, intensifying the development of the educational system;

4. Electronic library systems as part of a single open educational space;

5. Research universities: scientific research and innovation in higher education institutions (Zdioruk, 2011).

The concept of "The New Education" is based on new forms of higher education and has arisen as a result of "new general education programs designed to produce bread of study through the selection from a variety of elective courses" (Penprase, 2018). Any effective education strategy should include some consideration of the human condition, the ways in which technology affects people of all socio-economic levels (Penprase, 2018).

"The new geo-politics" in the field of higher education involves the formation of mutual understanding and globalization of forms of learning. The physical sciences are most wide-spread in modern higher education in the context of the concept of geopolitics in education, but the humanities and social sciences play a crucial role in shaping understanding between countries (Marginson, 2018). The geopolitics of higher education transforms competition and forms of learning.

Competition has become institutional, transforming universities into competitors (Musselin, 2018). Competition forms Entrepreneurship higher education, which aims to form an entrepreneurial way of thinking of students. Accordingly, forms of learning are transformed: students' general knowledge requires more development than personal qualities. At the same time, the compliance of forms and programs of education with the needs of students remains a problematic issue. Students believe that the educational programs in the universities do not meet the needs to ensure the formation of entrepreneurial thinking (Akhmetshin et al., 2019). 


\section{Conclusion}

According to the results of the study, it has been revealed that social-economic and political changes are impossible without a structural reform of the national system of higher and vocational education and training. According to the world experience, education in Ukraine should carry out appropriate reforms in education, because in order to make the country's economy competitive, it is necessary to have a sufficient number of highly qualified specialists. The priority task is to modernize education in line with current international requirements, including the use of new forms of education. The transition to teaching, taking into account the requirements of the Bologna process in Ukraine, implies a significant increase in students' independent work in the learning process.

The design of educational structures and the introduction of new models and training programs are still relevant. The normative-legal documents on higher education indicate the relevance of constant updating of the content of education and organization of the educational process, in accordance with democratic values, market principles of the economy, modern scientific and technological achievements. Integration in the field of education and science is the implementation of international norms and standards in education. For the further development of new forms and methods of training, the use of information technology, it is necessary to solve the following strategic problems: systematization, (that is, there should be a single strategic policy in the field of educational process), complexity; standardization (existing information education systems are qualitatively different from each other by models, technologies, forms of organization); effective regulatory support. The best way to modernize education is to introduce innovative training: distance education, open vocational, dual education, virtual enterprises and business training centers. In Ukraine, there is a need to accelerate the introduction of dual education, which will partially change the problems of unemployment and employment of students. Today all these changes are supported by the state, so it is necessary to involve to the process more educational institutions.

\section{References}

Akhmetshin, E. M., Mueller, J. E., Yumashev, A. V., Kozachek, A. V., Prikhodko, A. N., \& Safonova, E. E. (2019). Acquisition of entrepreneurial skills and competences: Curriculum development and evaluation for higher education. Journal of Entrepreneurship Education, 22(1), 1-12.

Colley, H., Hodkins, P., \& Malcom, J. (2003). Informality and formality in learning. Leeds, UK: Lifelong Learning Institute University of Leeds.

Corney, G., \& Reid, A. (2007). Student teachers' learning about subject matter and pedagogy in education for sustainable development. Environmental Education Research 13(1), 33-54. https://doi.org/10.1080/13504620601122632.

Duffin, E. (2020). E-learning and digital education - Statistics \& Facts. Retrieved from https://www.statista.com/topics/3115/e-learning-and-digital-education/

Eurostat. (2014). Eurostat Regional Yearbook 2014. Volume 3: Education. Retrieved from https://ec.europa.eu/eurostat/documents/3217494/5786237/KS-HA-14-001-03-EN.PDF/43efce65-4b6c-4105-8c 93-a6fce178c5ee

Eurostat. (2020). Public expenditure on education in current prices, by education level and programme orientation. Retrieved from https://appsso.eurostat.ec.europa.eu/nui/show.do?dataset=educ_uoe_fine04\&lang=en

Gallivor, R., \& Bradley, E. (2012). Why durable teaching changes are elusive and what might we do about it? Journal of Reading Recovery, 3, 42-55.

Ishchenko, A. (2014). Global tendencies and problems of the educational development: Consequences for Ukraine. The analytical note. Retrived from http://www.niss.gov.ua/articles/1537

Lindgren, N., \& Oehman, J. (2018). A posthuman approach to human-animal relationships: Advocating critical $\begin{array}{llll}\text { pluralism. Environmental } & \text { Education }\end{array}$ https://doi.org/10.1080/13504622.2018.1450848.

Lunyachek, V. (2011). Problems of the education system development of Ukraine in times of crisis. Public Policy and Administration, 10(1), 67-78. https://doi.org/10.5755/j01.ppaa.10.1.229

Marginson, S. (2018). The new geo-politics of higher education. Global cooperation, national competition and social inequality in the World-Class University (WCU) sector. Working paper \#3. London, UK: Centre for Global Higher Education, UCL Institute of Education.

Maslova, V. (2004). Fundamentals of Andragogy. Terminological Dictionary, Mariupol, Ukraine: Pryazovskyi State 
Technical University.

Ministry of Education and Science of Ukraine. (2018). Dual Education. Retrieved from: https://mon.gov.ua/ua/osvita/profesijno-tehnichna-osvita/dualna-osvita

Musselin, C. (2018). New forms of competition in higher education. Socio-Economic Review, 16(3), 657-683. https://doi.org/10.1093/ser/mwy033

Ogneviuk, V. (2014). Acme-personality, acme-society, acme-country. Retrieved from: http://elibrary.kubg.edu.ua/id/eprint/4917/1/V_Ognevyuk_05_14_konf_IS.pdf

Penprase, B. E. (2018). The fourth industrial revolution and higher education. In N. Gleason (Ed.), Higher education in the era of the fourth industrial revolution, 207-229. Singapore: Palgrave Macmillan. https://doi.org/10.1007/978-981-13-0194-0_9

Semenets-Orlova, I. (2018). Tendencies in reforming the educational systemsépiof modern Ukraine: national and regional aspects. Ukrainian Assembly of Doctors of Sciences in Public Administration, 1(12), 191-200. https://doi.org/10.31618/vadnd.v1i12.91

The Times Higher Education. (2020). World University Ranking. Retrieved from https://www.timeshighereducation.com/world-university-rankings/2020/world-ranking\#!/page/0/length/25/sort_ by/rank/sort_order/asc/cols/stats

Tkachenko, L. (2015). Vouchers for the training of persons aged 45 years as instruments of active labor market policy. Demografia ta socialna ekonomika, 2(24), 41-52. http://doi.org/10.15407/dse2015.02.041

World Bank. (2018). The World Bank Annual Report 2018. Retrieved from: http://documents.worldbank.org/curated/en/630671538158537244/pdf/The-World-Bank-Annual-Report-2018.p df https://doi.org/10.1596/978-1-4648-1296-5

Zdioruk, S. (2011). Formation of a single open educational and scientific space of Ukraine: optimal use of the means of providing advance development. National Institute for Strategic Studies, 2, 43-45. 